\title{
Total Quality Management in Higher Education in Kingdom of Saudi Arabia
}

\author{
Bandar Alkhalil \\ Information System department Faculty of \\ Computing \& Information Technology King \\ Abdulaziz University \\ Jeddah, Saudi Arabia
}

\author{
Zakria Oribe \\ Information System department Faculty of \\ Computing \& Information Technology King \\ Abdulaziz University \\ Jeddah, Saudi Arabia
}

\begin{abstract}
The paper is about TQM in high-level education in Kingdom of Saudi Arabia. The article will focus on the research of TQM in advanced education in Kingdom Saudi Arabia and also in the world. It also includes the definition, literature review, methodology and also the proposed model of TQM in Saudi Arabia. The research will focus on all the details, and in general what TQM entails as a management control. TQM according to the research it is applied in both academics and also economic sectors. Total quality control is a result of the future technology that helps in improving both academic and financial standards.
\end{abstract}

\section{Keywords}

Universities, Quality, Total Quality Management(TQM), High-Level Education, Continues Enhancement, Academic Quality, Saudi Collage, Saudi Universities.

\section{INTRODUCTION}

TQM has been a primary management technique in many of the fields including educational and economic [1]. Many of the universities globally have enacted this method to improve their quality of high-level education. Countries like USA, Russia, France, have assimilated this TQM in their universities system [2]. This is to make students more involved in the general work and also the direction of the school. Is Saudi Arabia one of the second countries to assimilate this technique in its all universities in the Middle East? The central question is that will TQM help improve 5the academic standards of schools in Saudi Arabia and also in the world? And the answer is yes, TQM will help many of the universities to harness their control and also make it very easy to achieve their objectives [3].

Saudi Arabia is not only an economic giant but also due to the implementation of TQM in the high-level education, it has become an academic giant. Many students not just only from Saudi Arabia but also from other countries in the world, including UAE, Indonesia, Iraq, Morocco, Egypt and also Kuwait [2]. All those students have gone to Saudi Arabia to pursue their education. This is because due to the implementation of TQM in Saudi Arabia the standards and also the quality of education has become better. It's now on the level of the superpowers such as united states of America and Russia.

\section{IMPORTANCE OF TOTAL QUALITY MANAGEMENT}

TQM helps in improving the standards of an organization and also making it better of a working place [4]. Good management will improve the quality of products in an organization [5]. In a basis of educational the products are the students and the societies are the universities, whereas due to right and quality management techniques, the products which are the students become more successful due to an implementation of this method. TQM is applied in the navy forces, where the Navy used the PDCA cycle to drive the power issues to faster resolutions [6]. Also, they used the complete quality control in the active management in the steering committees [3]. TQM has been the primary implementation in many of the companies and also industries in the world; this is because it improves the quality and also the standard of the industry [3].

\section{DEFINITION OF TOTAL QUALITY MANAGEMENT}

TQM is a round system of management which is based on the principle, which states that every staff member must be fully committed to maintaining high standards of work in each and every part of company activities [7]. Also, TQM is an administration attitude that uses the human resources in an optimum way to achieve the organization or company goals [8] [9]. The term quality is defined as a taste or customer requirements, which means that what the customers need at most is regarded as quality[10]. Quality can be applied both in services and also products. In industries, both the services and outputs can use, but when it comes to educational basis, only the services will apply. The lecturers must be quality services to the students. Management is defined as the guidance or protection of a particular institution or organization to facilitate smooth running of the activities [11].

\section{TOTAL QUALITY MANAGEMENT IN HIGH-LEVEL EDUCATION}

TQM has been implemented by many universities in the world. This has been very demanding because advance education is one of the most critical stages of education [12]. Many of the countries have implemented this technique due to the success of some of the countries that have used the similar technique in their school system. Some of the countries include the USA whereby $80 \%$ of the universities have implemented this method, and it has been a total success in accomplishing their goals [10].

Advance education introduces students to the outside world where one will work in the biggest companies and also industries in the world. By teaching the students how to be prepared in the working sectors the teachers should also give them assignments to go and research about advantages of TQM. And by this, they will prepare them to be the future researchers and also scientists [13].

TQM has helped in the production of qualified human resources this is to imply that TQM has produced well educated and skilled students who are ready to face their future careers and help in improving the economy of a 
particular country [14]. TQM has also assisted in the training of students for their future research careers such as being scientists and also researchers. And by this, the world will become a better place due to a high efficiency of information from the researchers and also the scientists [10].

Efficient management of teaching technique is also as a result of an implementation of TQM in advance education [13]. The method has produced many teachers due to the vast supply of knowledge the students have. Teaching profession also requires management, and through TQM, it has helped provide quality teachers and also quality students.

TQM has also supported extending the life chances of many people and also creating good men and also women to the world both economically and also socially. Has made TQM the best management technique to adopt globally [13].

\section{LITERATURE REVIEW}

The literature review of the paper will focus on the whole quality management in advance education in Saudi Arabia. The authors argue that education is not fully defined as knowledge if it's not of quality [10]. The primary importance of education is to earn experience and share it with other people. Sims did not only refer to school has been quality, but also good education must have good standards [10].

The concept of TQM is applied in both academics and also in economics, ridge regarded to TQM as a tool to facilitate success or attain the goals of a particular institution or organization [3] schools, and also industries apply this concept of total quality management, products then.

Many authors believe that TQM as a management philosophy can help solve many of the problems in the high-level education sector this is by restraining students and making them more reliable to qualify to be good managers and hence making them more of quality [11].

Many of the universities are competing for the topmost level of education, but what will determine is the quality of their products and also the quality of the services they offer. To ascertain the quality of the goods the alumni's of the universities will be analyzed, and the question will be, are they successful or they are just failures [11].

Saudi Arabia has one of the Middle East countries have also seen the advantage of implementing TQM in its all universities. The main reason to implement this technique is that is a tool to enhance the quality of high-level education in Saudi Arabia. TQM has been gaining and also maintaining competitiveness in many of the universities globally. This is because every school wants to be at the topmost level, and be referred as an international university. And this will result from his quality education and also management [15].

TQM has not only improved the economic standards but also has much improved the education standards in Saudi Arabia. Saudi Arabia wants to be equal to that superpower country that has also implemented TQM in their universities. The school ministry in Saudi Arabia has come up with a change in advance school system they have started offering different courses in TQM this is to make TQM a primary management technique in the universities. The implementation of this method has led to the success of both the students and also the teachers'. And currently, Saudi Arabia has one of the most improved education systems in the world [4].

\section{RESEARCH METHODOLOGY}

The research work was done using case study. Many studies were done in different parts of the world and also in various fields. The first survey was done on the implementation of TQM in advance education in the world, whereby from the study about $60 \%$ of the universities in the world have adopted this technique. Comparing this the recent ten years whereby on $20 \%$ of the schools had implemented this method and they were only the superpowers countries which had implemented it in their education system. According to the study, there has been a fast rise in percentage which indicates that TQM is helping many of the universities globally.

The second study which majored mainly on the implementation of TQM in Saudi Arabia was analyzed according to the data taken from different schools in Saudi Arabia. The data was collected from the students in various universities in Saudi Arabia through interviews and also observations. From the study, many of the schools in Saudi Arabia have implemented TQM, and only about $10 \%$ of the colleges have not applied the technique.

All the data were analyzed, and it came out to be that TQM is one of the management techniques that have led to an improvement of education standards of many of the universities globally.

\section{PROPOSED MODEL TO IMPLEMENT TOTAL QUALITY MANAGEMENT IN HIGH-LEVEL EDUCATION IN SAUDI ARABIA}

Saudi Arabia is very much concerned in an improvement of its advance education standards hence it has come up with a model to enable good management and also to satisfy the student requirements. The model consists of four phases which make up the whole model processes. 


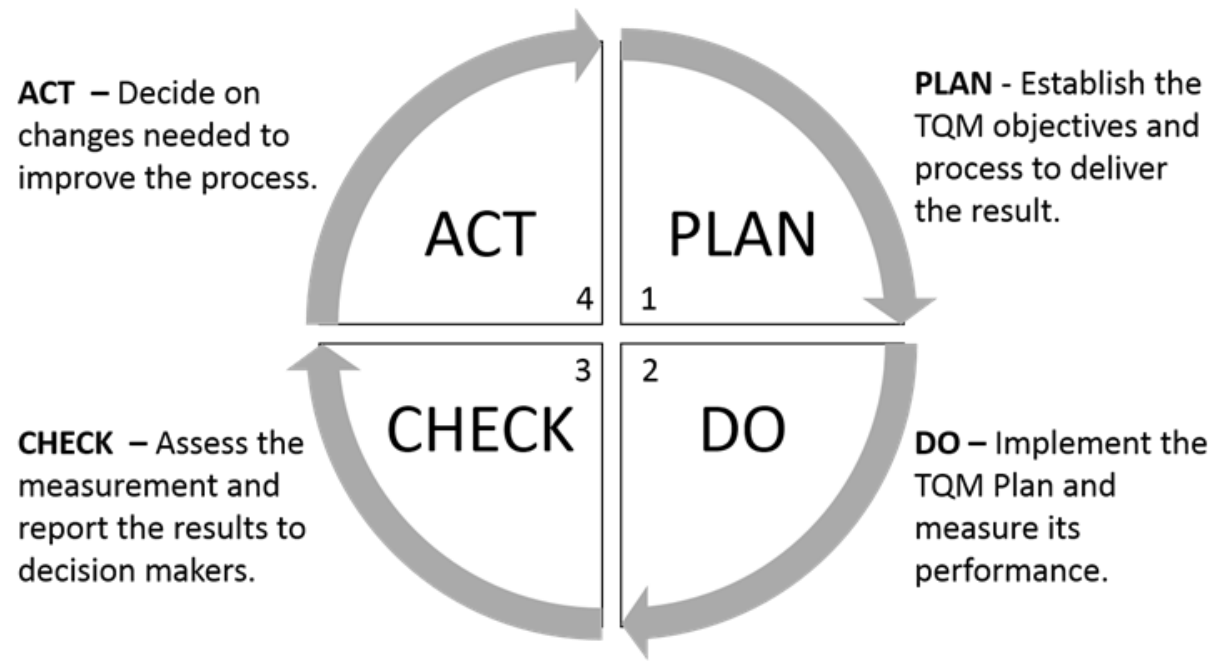

Fig 1: Total Quality Management Model in High-Level Education

\section{ANALYSIS OF TOTAL QUALITY MANGEMENT PROPOSED MODEL}

The model shows all the good qualities that an institution or an organization must follow in order to be successful and attain their goals.

\subsection{Plan Phase}

In the planning phase, the administration is responsible to establish the TQM policy, aims, and, process that lead to obtaining the desired results.

In order to implement TQM philosophy in a successful way, the administration should identify the customers carefully. The usual customers of the education firm usually are the student, employers, and the University Board.

\subsection{Do Phase}

In do phase, the process and objectives that constructed in the previous phase will implement it. And then after that will be measured against the rule and standard that are set up in the planning phase in order to evaluate the quality of implementation.

\subsection{Check Phase}

In this phase, the procedure will be assessed and the outcomes will be analyzed. Some activities should take place at this stage such as performing a comprehensive evaluation of each process, monitor the application of the regulations and rules strictly help in enhance the processes.

\subsection{Act Phase}

In the acting phase, decisions of change will be taken here to improve the process. The improvement can come in several forms such as encourage the participants in the TQM process.

\section{CONCLUSION}

In conclusion, many of the universities all over the world have enacted this technique. Many of them have come to success but a few of them have failed this is due to poor financial standards and also poor management of the institutions. Those that have success has seen the better part of it but fails, it requires more composure to enact such a technique. The research ease successful, though there were some of the problems faced, including hostility of some of the students and also the lack of full information from some of the students who are shy .but lastly the research was successful [13]. Saudi Arabia has developed much in the sector of academics. This is because the implementation of TQM has made the education system easier. This has made the quality of advance education better compared to the time when the TQM was not implemented. Finally, the result from implementation of the TQM in advance education will be reflected on the quality of higher education at all such as the quality of the teaching program, the quality of personnel, the quality of rule, and lows, the quality of students and curriculum. Increasing the excellence in all education factors leads to quality of highlevel education institution at all.

\section{REFERENCES}

[1] Nina Becket and Maureen Brookes. Quality management practice in higher education-what quality are we actually enhancing? Journal of Hospitality, Leisure, Sports and Tourism Education (Pre-2012), 7(1):40, 2008.

[2] Lawrence RP Reavill. Quality assessment, total quality management and the stakeholders in the uk higher education system. Managing Service Quality: An International Journal, 8(1):55-63, 1998.

[3] Natasha Ridge. Education and the reverse gender divide in the Gulf States: Embracing the global, ignoring the local. Teachers College Press, 2014.

[4] Habiba Abbasi and Pratiksha Rai. Management education-a challenge: Tqm as a solution. Quality Management Practices, page 447, 2008.

[5] W Edwards Deming. Improvement of quality and productivity through action by management. National productivity review, 1(1):12-22, 1981.

[6] Roberto P Caravajal. Tql implementation process in the us navy: A case study onboard the uss carl vinson, and its applicability to chilean navy warships. Technical report, NAVAL POSTGRADUATE SCHOOL MONTEREY CA, 1996.

[7] Juan Jose Tari, José Francisco Molina, and Juan Luis Castejon. The relationship between quality management 
practices and their effects on quality outcomes. European journal of operational research, 183(2):483-501, 2007.

[8] A Aletaiby, U Kulatunga, C Pathirage, et al. Key success factors of total quality management and employees performance in iraqi oil industry. In 13th IPGRC 2017

[9] Andrew WT Lau, SL Tang, and YS Li. The level of tqm application by construction contractors in hong kong. International Journal of Quality \& Reliability Management, 32(8):830-862, 2015.

[10] Serbrenia J Sims. How to improve student outcomes in higher education by applying total quality management tools. Total Quality Management in Higher Education, Praeger Publishers, Westport, CT, pages 127-141, 1995.

[11] Hatem El-Gohary. E-Marketing in Developed and Developing Countries: Emerging Practices: Emerging Practices. IGI Global, 2013.
[12] Anthony D Cortese. The critical role of higher education in creating a sustainable future. Planning for higher education, 31(3): 15-22, 2003.

[13] Mark Thompson. Saudi Arabia and the path to political change: National dialogue and civil society, volume 159. IB Tauris, 2014.

[14] Ching-Chow Yang. The impact of human resource management practices on the implementation of total quality management: An empirical study on high-tech firms. The TQM Magazine, 18(2):162-173, 2006.

[15] Majed Alamri. Higher education in saudi arabia. Journal of Higher Education Theory and Practice, 11(4):88, 2011. 